\title{
Theology and practice of Christ Apostolic Church on Bible inspiration and its authority in the context of Evangelical theology
}

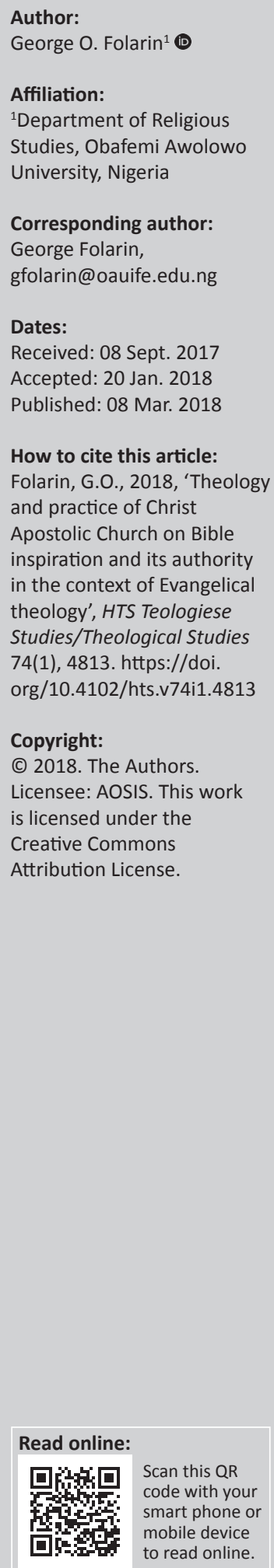

\begin{abstract}
The motivation for this study originated from a review of literature which led the current researcher to the realisation that not much critical study has been performed on the theology and practice of Bible inspiration and its authority in Christ Apostolic Church (CAC). This article set out to identify the tenet of faith of the church on inspiration and authority of the Scriptures, locate this tenet in the context of Evangelical theology and compare the initial understanding of the concept of Bible inspiration in CAC with the way it is perceived by the church members today. Primary sources of data for the work comprised the Bible, editions of CAC constitution and structured interviews. Secondary sources of data comprised Bible commentaries, books, journal articles and the Internet. Data collected were analysed using Conservative Evangelical theological framework. The study discovered that CAC held to word-for-word inerrancy of the Scriptures, even of its vernacular translations, and its binding authority on Christians in all areas of their lives. The study revealed that the belief of CAC on Bible inspiration and its authority located CAC at the centre of Evangelical theology which researchers have identified as inerrancy. Finally, the study discovered that the initial position of CAC on the inspiration and authority of the Bible remained the same as held by contemporary members of the church. The work provides theological relevance for the study of one of the doctrines of Pentecostalism in Nigeria.
\end{abstract}

\section{The tenet of Christ Apostolic Church on inspiration and authority of the Bible}

The first tenet of Christ Apostolic Church (CAC) states, 'We believe and hold: The divine inspiration and authority of the Holy Scriptures' (Constitution and Doctrines 1998:23). Church tenets are articles of faith supposedly built on the correct interpretation of the Scripture. Because church tenets are at best human interpretations of divine truths, they may sometimes be questionable if the particular theological tenets are built on faulty exegesis and poor hermeneutics (Morris 2012:26). Otten puts this issue thus, '[...] revealed truths are objectively permanent and immutable ... (but) their subjective apprehension and outward expression admits of progress' (Otten 1922). Morris therefore cautions, '[...] when ... tenets are taken to an extra-biblical extreme, or when modified by the assimilation of non-biblical nuances, the result is a distortion of orthodoxy' (Morris 2012:33). This is why church tenets need re-visiting, re-evaluating and reworking at intervals to make sure that they are better conformed to objective interpretation of the Scripture (cf. Folarin 2013:701). The term 'tenets' is used in this article for CAC dogma or doctrines accepted by the Church to guide the religious practises of its members.

The four versions of the CAC constitution (Constitution and Doctrines 1961; 1970; 1995; 1998) list first the tenet of inspiration and authority of the Bible. The veracity of the claim of the late General Evangelist of CAC, David O. Babajide, that, '[...] lati owo Emi Mimo ...ni a ti fi awon ilana ati eko ijo CAC le awon baba wa ninu igbagbo ... l'owo' (Babajide 1980:1) (Translation: CAC practices and doctrines '... were handed down by the Holy Spirit to our founding fathers') is doubtful. The current research shows that CAC inherits its tenet on the inspiration and the authority of the Bible from the Evangelicals that existed before it. The church also shares some of its other tenets with the Pentecostals that existed before it.

\section{Inspiration and authority of the Bible: Christ Apostolic Church in the context of Evangelical scholarship}

Although the belief in inspiration and the authority of the Bible is common in CAC, the church only inherited the article of faith. In fact, the belief in inspiration and authority of the Scriptures is 
common to both Evangelical and Pentecostal churches. Hunter (1963) points out that the inspiration and the authority of the Bible is:

Perhaps the most important element of Evangelical theology its particular conception of the Bible as ... perfect, inerrant ... and infallible with regard to all spiritual, ethical and religious matters. (p. 61)

Some other scholars on Evangelicalism agree with Hunter's submission that inspiration and authority of the Scriptures is the most important element of Evangelical theology (Steiner 2006:46). But although Pentecostal theology inherited the belief in the inspiration and authority of the Bible from Evangelical theology, Pentecostalism does not have a single theology of Bible inspiration and authority (Kay 2004:71-83). Some of them hold to the infallibility of the ideas in the Bible but not the words used to convey the ideas.

Prior to the time when the description of the tenet of faith of CAC on the inspiration and authority of the Bible appeared on the CAC (Worldwide) web page (Christ Apostolic Church n.d.), descriptions of the article of faith on inspiration and authority of the Bible were private and personal as each church minister interpreted the tenet as he or she understood it. It is of course difficult to explain the demotion of the doctrine on Bible inspiration and its authority from the first to the eighth tenet, contrary to what is written in all the available printed editions of CAC constitutions. Whoever was responsible for moving the tenet on the inspiration and the authority of the Bible from the first to the eighth on the web-page was probably ignorant of the fact that the doctrine of inspiration is fundamental to Christianity. Yoder and Martin correctly note thus, 'The inspiration and authority of the Bible is the foundation upon which the entire edifice of Christian truth is standing. If this foundation falters the whole Christian faith goes with it' (Yoder \& Martin 1985:30). Such observations underscore making the tenet on the inspiration of the Bible the first among other tenets because other doctrines depend on the fact that the Bible is the word of God.

Yong rightly recognises, 'Pentecostals consider conservative evangelicals their allies and agree with them about the authority, infallibility and even inerrancy of the Bible' (Yong 2011:3). This information is significant because the progenitors of CAC came from Evangelical churches of that time like the Anglican and the Methodist churches. Litke (2017) describes this Evangelical-Pentecostal concept of Bible 'inspiration' as:

[God] superintended the writing of men who wrote exactly what God intended. They used their own styles and expressed their thoughts freely knowing what they meant. Yet, through the Holy Spirit, God at the same time determined the content and controlled the accuracy of all they wrote. (n.p)

Charles C. Ryrie's (1972) definition of inspiration is more comprehensive and it better represents Evangelical and Pentecostal definitions of the concept. He defines it as:

God's superintendence of the human authors so that, using their own individual personalities, they composed and recorded without error ... [God's] revelation to man in the words of the original autographs. (p. 38)
This definition raises several vital points. The first is that God superintended but did not dictate the materials in the Bible. The second is that God employed human authors and their own individual styles in the writing. The third is that the product, in the original manuscript, was without error. Harold Lindsell's (1976; 1981) explanation of the concept is clearer:

However limited may have been their knowledge, and however much they erred when they were not writing sacred Scripture, the authors of Scripture, under the guidance of the Holy Spirit, were preserved from making factual, historical, scientific, or other errors [...]. (pp. 30-31)

There are at least four views of Bible inspiration. Put simply, these are, firstly, that the Bible is not the word of God. This view is liberal. It conceives of the Bible only as a human book written by geniuses just like the novel Macbeth, and the song Zombie. Secondly, that the Bible contains the word of God. At best, this view claims that there are parts of the Bible that are truly words of God but denies that all the contents of the Bible are words of God. This is called 'partial inspiration theory'. The third is that the Bible becomes the word of God. This is also called the 'existential theory of inspiration'. This view claims that any part of the Bible which convicts its reader is the word of God for that person at that time. One problem with this view is that the text of the Bible which convicts one person may not convict another person and so what 'is' the word of God for one person 'may not be' the word of God for another person. The fourth and the last view is that the Bible is the word of God whether it convicts its reader or not. This last view is the Evangelical and Pentecostal view of the inspiration of the Bible, but the view goes beyond this. The view that the Bible is the word of God has led to the doctrinal development of the verbal plenary inspiration of the Bible (Ryrie 1972:38-40; cf. Duffield \& Cleave 1983:22-25).

Although no Reformer ever defended verbal inerrancy of the Scripture:

[...] their theological successors, among them Johannes Andreas Quenstedt (1617-1688) and Abraham Calovius (1612-1686), defended the verbal inspiration of the entire Bible and developed the principle of biblical infallibility. (Jeanrond 1992:433-443)

The doctrine of Bible inspiration as conceived by the Evangelicals and Pentecostals is thus a post-Reformation development. McKim captures the issue well when he notes that the doctrine of the - inerrancy of Scripture was a way of asserting Scripture's authority on the basis of its complete truthfulness and accuracy in all details (McKim 1992:10321035). Feinberg gives a simple definition of inerrancy as:

Inerrancy means that when all facts are known, the Scriptures in their original autographs and properly interpreted will be shown to be wholly true in everything that they affirm whether that has to do with doctrine or morality or with the social, physical, or life sciences. (Feinberg 1980:294; cf. Lagoon 2015:n.p.)

Contemporary conservative Bible scholars make a clear distinction between the original copies of the Scripture called autographs and other copies produced from the original by 
scribes and editors. The claim to the inerrancy of the Scriptures concerns only the original copies produced by various writers of the Bible and not the extra copies made by copyists. Duffield and Cleave (1983) define inerrancy of the Scripture in the same vein as:

$[\ldots]$ in its original autographs the Bible contains no mistakes. In the original languages in which it was written, it is absolutely infallible - without error whatever. This has been the position of all the confessions of the great evangelical churches down through the years. (p. 15)

The Baker Illustrated Bible Dictionary succinctly puts the issue thus, 'The locus of inspiration, inerrancy and infallibility is the original manuscripts and not the translations. A translation is reliable when it accurately reflects the meaning of the inspired originals' (Longman 2013:n.p.). This shows that the affirmation that there is no error in the Bible concerns the original copies written by, say, Amos, Isaiah, Malachi, etc. in the Old Testament and Paul, Peter, John, etc. in the New Testament. Of course, there are errors in other Hebrew, Greek, Hausa, Igbo Yoruba, etc. copies made from copies initially written by the writers of the books.

As recently as 1978, the International Council on Biblical Inerrancy sponsored an international conference of Evangelicals to re-define Bible inspiration more precisely. The conference qualified Bible inspiration with two words: infallibility and inerrancy (International Council of Biblical Inerrancy n.d.:n.p.). The conference made five summary statements. The two most relevant of the five summary statements on inspiration of the Bible are as follow:

1. Holy Scripture ... written by men prepared and superintended by [the Holy] Spirit, is of infallible divine authority in all matters upon which it touches: it is to be believed, as God's instruction, in all that it affirms; obeyed, as God's command, in all that it requires; embraced, as God's pledge, in all that it promises.

2. Being wholly and verbally God-given, Scripture is without error or fault in all its teaching, no less in what it states about God's acts in creation, about the events of world history, and about its own literary origins under God, than in its witness to God's saving grace in individual lives. (Chicago Statement of Biblical Inerrancy n.d.:n.p.)

The conference also made 19 affirmations which are summarised in the three sentences stated below. First is that the Bible is normative in all its parts, words and claims. Secondly is that the Bible consists of the words of God given to the writers of the Scriptures. Thirdly is that the writers were supervised by the Holy Spirit in the course of their writing to prevent error in the autographs (International Council of Biblical Inerrancy n.d.:n.p.). Slick (n.d.) clarifies the concept thus:

Verbal plenary inspiration means that every word found in the Bible is given ... by God (verbal), everything in the Bible is authoritative (plenary), and every word is also divinely directed (inspired). (n.p.)
It needs pointing out here that the few errors which crept into copies made from the original manuscripts and translations of the Bible do not imply that the versions of the Bible available to the church today are not trustworthy. The Bible is reliable for many reasons. The errors found in the copies and versions do not affect the doctrines in them, they only affect minor issues and application of textual criticism to the available manuscripts has demonstrated that the original words in the autographs can be restored. Evidence that has been adduced for the divine origin of the Bible includes the many supernatural changes that encounters with the message of $\sin$ and salvation in the Bible have brought into peoples' lives, the many predicted and fulfilled prophecies the Bible contains, the distribution and indestructibility of the Bible and the many archaeological findings that support its claims (Litke 2012:n.p.). Kenyon is still in order:

It cannot be too strongly asserted that in substance the text of the Bible is certain. Especially is this the case with the New Testament. The number of manuscripts of the New Testament, of early translations from it, and of quotations from it in the oldest writers of the church is so large that it is practically certain that the true reading of every doubtful passage is preserved in some one or other of these ancient authorities. This can be said of no other ancient book in the world. (Kenyon 2011:23)

While Kenyon's primary focus was on the extant Greek manuscripts of the New Testament, many New Testament scholars such as Wright and Bloomberg are of the view that the statement also holds true for other translations. Of course, Christianity is faith and not 'evidence' based and so does not need proof. Ockenga in his 'Foreword' to Lindsell's book, The Battle for the Bible, rightly observes:

$[\ldots]$ inerrancy is the watershed of modern theological controversy ... The attitude we have toward the trustworthiness of Scripture determines our later position, not only on faith, but also on practice. The evidence that those who surrender the doctrine of inerrancy inevitably move away from orthodoxy is indisputable. (Ockenga 1976, 1981:iv)

Oshun insightfully observes that members of Africa's prophetic churches, among which is CAC, generally accept '... the infallibility, inviolability and the final authority of Scripture for faith and conduct in all things' (Oshun 2016:25). Just as Conservative Evangelical churches hold to the inerrancy and infallibility of Scriptures, CAC adheres to it, supporting the belief from 2 Timothy 3:16-17. The New International Version (NIV) translates 2 Timothy 3:16a as 'All Scripture is God-breathed', the English Standard Version (ESV) as 'All Scripture is breathed out', and the New American Standard Version (NASV) as 'All Scripture is

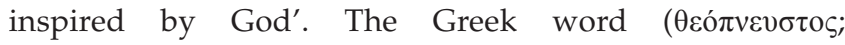
transliteration: theopneustos) translated 'God breathed' also means, divinely inspired and 'inspired by God' (Cf. Arndt \& Gingrich 1957:357). Conservative Bible scholars have pointed out that the first part of 2 Timothy 3:16 teaches that every part of the Scripture is breathed out by God. By extension, this means that the Scripture is not of human but 
divine origin. The adjective translated 'all' could also be translated as 'every' (White 1956:175-176). The immediate referent of 'every Scripture' here is each book of the Old Testament.

Another important text of the Bible often used by CAC to support the doctrine is 2 Peter 1:20-21. Ryrie, representing the Conservative Evangelical position, explains 2 Peter 1:21 thus, 'For prophecy never had its origin in the human will, but prophets, though human, spoke from God as they were carried along by the Holy Spirit' (NIV), meaning that the writers of the Scriptures were carried along by the Holy Spirit while writing their books. Ryrie concludes from this that 'The Spirit ... [was] a co-author with each human writer' of the books of the Bible (Ryrie 1972:41). From such a Conservative Evangelical context, albeit at its emergent stage, came the patriarchs and matriarchs of CAC: The David Odubanjo and Isaac B. Akinyele of the Anglican Church, and Samuel G. Adegboyega of the Methodist Church. These Evangelical churches held to the belief in the full inspiration and authority of the Bible in line with other holiness churches of the time and they subsequently bequeathed this doctrine to the churches that emerged from them, among which was CAC. CAC interprets the Scriptures literally to include periods (full stops, comas and question marks) even in the vernacular versions of the Bible. Texts such as Matthew 5:18 ('... not an iota, not a dot, will pass from the Law until all is accomplished', KJV) and Matthew 24:35 ('Heaven and earth will pass away, but my words will never pass away', NIV) are cited by the progenitors of CAC in support of their hermeneutics. This arose from their commitment to 'take God at his word' (Adeoye 2017). The extent to which CAC therefore held on to its tenet of inspiration and authority of the Scriptures was more extreme than the way its Conservative Evangelical neighbours of that time held on to the article of faith.

\section{The experience of Christ Apostolic Church on the inspiration and authority of the Bible}

The CAC on its website explains its article of faith on Bible inspiration thus:

The Church believes that both the Old and New Testaments, comprising the Holy Scriptures, were written by individuals through guidance by the Holy Spirit. The Scripture contains what God wants Christians to believe about God, salvation, life, etc. (Christ Apostolic Church n.d.:n.p.)

To find out the understanding of the founding fathers and mothers of CAC as perceived by members of the church on one side, and the contemporary view of the church members on the inspiration of the Bible, a research instrument consisting of interview questions was designed to gather data. The first section of the question guide has items on the view of the progenitors and that of the contemporary members of CAC on the inspiration of the Bible as perceived by the church members. The second section contains question items on what CAC members perceived as the view of their progenitors and their contemporary view on the authority of the Bible. The contents of the questions were validated by a Professor of Religion in Obafemi Awolowo University and the difficulty level of the interview questions was pilot tested among 15 CAC members in an assembly in Garage Olóde between Ilé-Ifè and Ondó on 17 January 2017. Suggestions for better clarity of the test items made by those who participated in the pilot study were later incorporated in the instrument and a survey was carried out using the test items on the interview guide designed for the purpose. The results are presented in Table 1.

The data presented in the tables in this article were gathered from two regions in Nigeria where the researcher had

TABLE 1: Members' perception of progenitors' belief on the inspiration of the Bible.

\begin{tabular}{|c|c|c|c|c|c|c|}
\hline \multirow[t]{3}{*}{ Item } & \multicolumn{6}{|c|}{ Responses } \\
\hline & \multicolumn{2}{|c|}{ North } & \multicolumn{2}{|c|}{ Southwest } & \multicolumn{2}{|c|}{ Total } \\
\hline & $n$ & $\%$ & $n$ & $\%$ & $N$ & $\%$ \\
\hline \multicolumn{7}{|l|}{ Inerrancy of vernacular translations of the Bible } \\
\hline $\begin{array}{l}\text { All parts of the Bible even in vernacular languages like Yoruba, } \\
\text { Hausa and Igbo are without error }\end{array}$ & 98 & 87.5 & 201 & 74.2 & 299 & 78.1 \\
\hline $\begin{array}{l}\text { All the books of the Bible even in vernacular languages like } \\
\text { Yoruba, Hausa and Igbo contain some errors }\end{array}$ & 10 & 8.9 & 60 & 22.1 & 70 & 18.2 \\
\hline Sub total & 112 & 100.0 & 271 & 100.0 & 383 & 100.0 \\
\hline \multicolumn{7}{|c|}{ Inerrancy of the letters, words, punctuations and sentences in the Bible } \\
\hline $\begin{array}{l}\text { Every letter, word, punctuation and sentence in the vernacular } \\
\text { translations of the Bible is without error }\end{array}$ & 91 & 81.3 & 178 & 65.7 & 269 & 70.2 \\
\hline $\begin{array}{l}\text { The letters, words, punctuations and sentences used in the } \\
\text { vernacular translations of the Bible have error }\end{array}$ & 16 & 14.2 & 74 & 27.3 & 90 & 23.5 \\
\hline No response & 05 & 4.5 & 19 & 7.0 & 24 & 6.3 \\
\hline Sub total & 112 & 100.0 & 271 & 100.0 & 383 & 100.0 \\
\hline $\begin{array}{l}\text { Only the doctrines and moral teachings of the Bible are without } \\
\text { error }\end{array}$ & 71 & 63.4 & 187 & 69.7 & 258 & 67.4 \\
\hline $\begin{array}{l}\text { All the claims of the Bible whether doctrinal, moral or scientific } \\
\text { are free from error }\end{array}$ & 31 & 27.7 & 68 & 25.6 & 99 & 25.8 \\
\hline No response & 10 & 8.9 & 16 & 4.7 & 26 & 6.8 \\
\hline Sub total & 112 & 100.0 & 271 & 100.0 & 383 & 100.0 \\
\hline
\end{tabular}


assistants who helped him gather data for the research: the Northern and the South-western. Data from the North were collected from Gombe, Zaria and Jos. Data from the Southwest were from Lagos, Ibadan, Ile-Ife, Ilesa and Ekiti. Responses comprised clergymen, elders or deacons or deaconess, and other church members for fair representation. One hundred and twelve respondents from the North and 271 from the Southwest participated in the research. The number of total respondents from the two regions was 383.

It was established through interview that the founding fathers and mothers of CAC were not aware of any difference between the original manuscripts of the Scriptures and the copies made later from them by copyists (Adeoye 2017). When the founding fathers and mothers of CAC therefore spoke of the Bible as the word of God, they meant the vernacular versions of the Bible they had in their hands.

What the church's first tenet of faith on '... divine inspiration ... of the Holy Scriptures' meant to the progenitors of the church was that the words in the vernacular Bibles are wordfor-word God's words and so contain no error. This understanding of the inspiration of the Scriptures is similar to the way Conservative Evangelical scholars interprets 2 Timothy 3:16 (Hendriksen 1957:301). Both the Evangelical and Pentecostal theologians agree that the Bible is 'the word of God'. However, there is no consensus among Evangelical scholars on the extent of the inerrancy.

Data displayed in Table 1, item 1a, reveal that CAC members perceived their progenitors' view of the Bible in all its parts in its various vernacular translations such as Yoruba, Hausa and Igbo as without error. Responses from the Northern region show that $98(87.5 \%)$ out of 112 and 201 $(74.2 \%)$ out of 271 from the South-western region held to the view of inerrancy of the Bible. In all, 299 (78.1\%) out of 383 respondents held to the view that CAC patriarchs and matriarchs believed that there was no error in the vernacular translations of the Bible. The majority view from both the Northern and Southern regions of Nigeria thus agree that the CAC founding fathers and mothers held to the plenary inspiration of the Bible. Table 1, item $1 b$, on the contrary, reveals that $70(18.2 \%)$ of the 383 interviewees held that CAC progenitors were of the view that there were errors in some parts of the Bible. Only $14(3.7 \%)$ out of the total 383 interviewees did not volunteer any response. The commanding opinion of CAC members therefore was that the church's progenitors held to the plenary inspiration of even the vernacular versions and translations of the Bible and that the Bible has no error.

Item $2 \mathrm{a}$ in Table 1 shows the responses of CAC members to their progenitors' belief on the inerrancy of the letters, words, punctuations and sentences in the Bible including the various vernacular translations. Data on item 2a show that $91(81.3 \%)$ of 112 respondents from the Northern region and $178(65.7 \%)$ of 271 from the South-western region held that CAC progenitors believed and taught that every letter, word, punctuation and sentence in the vernacular translations of the Bible is without error. In all, $269(70.2 \%)$ of 383 respondents held that the founding fathers and mothers of CAC believed in the verbal inspiration of even the vernacular translations of the Bible. Adeoye opined that the progenitors of CAC never differentiated between the original autographs and copies of Scripture (Adeoye 2017). They only knew of the English and the vernacular translations of the Bible. As found in Table 1 , item $2 b$, the interviewees who responded that the CAC founding fathers and mothers held that the letters, words, punctuations and sentences used in the vernacular translations of the Bible contain errors were $90(23.5 \%)$ of 383 interviewees. About 16 (14.2\%) of the 112 respondents came from the Northern region while $74(27.3 \%)$ of the 271 respondents came from the South-western region. As shown in Table 1, item 2c, only 5 (4.5\%) out of 112 from the Northern region and $19(7.0 \%)$ of 271 respondents from the Southwestern region failed to volunteer answer on the test item. The figures of those who provided no response add up to 24 $(6.3 \%)$. The conclusion from the data is therefore that CAC progenitors viewed every word, sentence and punctuation mark in vernacular translations of the Bible as having no error. The CAC, by implication, has taken the verbal inspiration of the Bible farther than the Evangelicals by adhering to the inerrancy of the translations of the Bible more than the Conservative Evangelicals who canvass for the inerrancy of the autographs of the Bible. If this is fundamentalism then CAC is a fundamentalist church.

Table 1, item 3, shows the findings, as perceived by CAC members, of their progenitors' view on the inerrancy of the doctrinal and moral teachings of the Bible. Item 3a revealed that $258(67.4 \%)$ out of 383 respondents limited the inerrancy of the Bible held by the progenitors of CAC to doctrinal and moral matters. Further analysis revealed that 71 of the respondents who held this view of CAC progenitors came from the Northern region while 187 of them came from the South-western region. This finding is at variance with the finding on item 2a where $269(70.2 \%)$ respondents held that CAC progenitors believed that every letter, word and sentence and not just the doctrinal and moral teaching of the Bible is without error. Table 1 , item $3 \mathrm{~b}$, on the contrary shows that $99(25.8 \%)$ of 383 interviewees were of the view that the patriarchs and matriarchs of CAC held that all the claims of the Bible whether doctrinal, moral or scientific were free from error. Further analysis of item $3 b$ reveals that 31 interviewees who held that the Bible is inerrant in all its claims - doctrinal, moral or scientific - came from the Northern region and 68 came from the South-western region. A possible conclusion from these findings is that not all who believe in the inerrancy of the Bible are willing to accept its accuracy on scientific issues. The confusion on the extent of inerrancy of the Bible is not limited to Pentecostal churches. In all, only 26 out of 383 interviewees abstained from responding to the item. The issue of the extent of Bible inerrancy has also divided Evangelical churches. This has led Lindsell to write his provocative book, The Battle for the Bible (Lindsell 1976; 1981). 
At the founding of CAC, as with some other African indigenous churches, the vernacular versions of the Bible, either in its English, Yoruba, Igbo or Hausa translation was regarded by many of the church's progenitors as dictated by God (Adeoye 2017; cf. Akinsulure 2017). Although the early members of the church were not exposed to the theological intricacies involved in the definition of the inspiration of the Bible, they in their simplicity accepted everything, including the punctuation marks, in the Bible as God's word without error. As reverential as the view of dictation appears to be, the view that the words of the Bible were dictated by God to passive human writers is mistaking. The early converts to the church therefore placed a very high value on the Bible as consisting of the literal word of God and as such, they read and used the Bible magically. Even in contemporary times, Psalms and other texts of the Bible are being regularly recited in prayers, Psalms are commonly read over water and olive oil for healing, and it was reported that on one occasion, Psalm 35 was written on a small sheet of paper, smartly tied, and given to a church member to hang on his neck as magical amulet. The use of Psalms as tira (or zeal, as some Aladura churches call it), is foreign to CAC. If such events occur in CAC and it is reported to the authorities of the church, and the erring 'prophet' would be sanctioned. A.J. Adelakun shared the encounter of one of his classmates in his Secondary school days with this researcher in which Psalm 35 was written, folded and given to him to hang on his neck for exam success. The candidate of course failed in the examination (Adelakun 2017).

Commenting on the use of Psalms in Aladura churches, Adeogun states, 'In the Old Testament literature the most widely read book is the book of Psalms ... because the Psalms speak, to real life situations' (Adeogun 2005:180). In agreement with Adeogun's observation, Ugwueye and Uzuegbunam capture the issue at stake thus:

When we read the Psalms, we hear our inner thoughts being expressed; our fears, doubts, reservations, our outbursts of rage, repressions, and frustrations; our dismay, dwindling hope, and desperation; and sometimes in the midst of it all, our lingering flicker of confidence that God can still arise to our aid. We find in the lines of the Psalms our inner, sometimes concealed helpless yearning for sudden vengeance wrought on our behalves by a force more powerful than our real or imagined enemies. (Ugwueye \& Uzuegbunam 2013:n.p.)

Like in other indigenous churches, CAC members often recite and apply Psalms in prayer.

A common chorus in CAC, beginning with the 1930 revival of Evangelist J.A. Babalola, was 'Ayangasi oloogun, b'owo mi ba te Samu, ayangasi oloogun' [To hell with the juju man if I lay my hand on Psalms]. Ademiluka too explains that among indigenous Christians, Psalms are regarded as weapons of warfare to combat the peoples' enemies who they perceive to be witches, sorcerers and others who hate them (Cf. Ademiluka 2006:53-62). Members of African Independent Churches inclusive of CAC thus use Psalms to protect and counterattack the evil tendencies in their enemies. Literates and illiterates in CAC use the Psalms of David in their warfare with demonic forces. Many times, one does come across illiterates who have memorised Psalms for use in prayers and there are ample testimonies that the Psalms work for them. Examples of such are narrated below.

Ogunkunle included CAC among the churches he studied on the use of Psalms in worship (Ogunkunle 2000). His most recent article on the use of Psalms also included the use of Psalms in CAC (Ogunkunle 2017:101-112). He used the book written by Olanrewaju, The Efficacious Power of Psalms in Daily Devotion, as the spring board for his study of CAC's use of Psalms (Ogunkunle 2017:105). Ogunkunle argues that the attraction of Africans to the use of Psalms in prayer is motivated by their worldview which holds that there are many wicked spirits that are out to persecute the righteous or the innocents. Olanrewaju on his part lists the Psalms that should be used in various difficult spiritual situations (Olanrewaju 1998). It is however the joint article authored by Alabi and Ariri-Chidomere that is definitive on CAC's use of Psalms in prayer. Their observation is that Joseph Babalola in 1928, following his call into the ministry, read Psalms 1-150 within 1 week because he could not sleep and that this was the origin of the use of Psalms in CAC (Alabi \& Ariri-Chidomere 2017:90; Cf. Oshitelu 2007:35). Through clear analyses, the duo shows that many other prophets and evangelists in CAC do use Psalms to deal with various problems.

The (late) Pastor Nathaniel Ogunlowo once explained how he used a Psalm to destroy the potency of a feared demonic power in Ahá in Òkè-Oògùn early in the 1970s. He narrated how during a masquerade called Alagbo, forbidden for outsiders to see except his devotees, the demonic power entered the house where he was praying to frighten him and those who heard the news thought that he, Ogunlowo, would die. He said that when he woke up the following day, he went to the house of the man in the masquerade where the owner of the masquerade showed him an effigy placed in a big bowl filled with local gin called Ògógóró. After much incantation on the effigy, the owner of the masquerade informed him that it was not possible for any human to lift up the effigy. Ogunlowo explained how after just reciting Psalm 8, he picked up the effigy, put it in his bag and went away with it. That singular event led to the conversion of the owner of the masquerade who later became a church elder in CAC Ahá (Ogunlowo 2006). In another instance, a woman with a delayed pregnancy was taken to the same prophet Ogunlowo in Ìluà, near Saki, around the same 1970. He said that after much prayer, he and one other Evangelist began to read out from Psalm 1 to 150 and that by the time they got to the last Psalm, the woman gave birth to an idol called Ère Àrònì with white beads hung on its neck (Ogunlowo 2006). Professor Olayiwola also recalled an experience in his life when he was young. According to him, he had a sore on his leg which refused to heal. A CAC prophet then came to their house 
and advised his mom to read Psalm 35 three times on water and then keep on washing the leg with the sanctified water. Olayiwola witnessed that the sore got healed in not more than 2 weeks afterwards (Olayiwola 2017).

The high view which CAC places on the Bible is not limited to Psalms. It extends to other parts of the Bible. The church justifies its position with Jesus' words in Matthew 5:18, 'Till heaven and earth pass, one jot or tittle shall in no wise pass ... unfulfilled' (KJV). It is useless pointing out to the founding fathers and mothers of the church that Jesus' referent was to the Old Testament. To the early fathers and mothers of the church, both the Old and the New Testaments are God's words. This is in consonance with the Evangelical teaching of plenary inspiration of the Bible. Again, although many Bible scholars agree that the emphasis of 2 Timothy 3:16 is on the profitability of the Scripture (Drury 2001:1230), CAC uses the text to support the inspiration of the Bible. While Timothy already knew that the Scripture is inspired, the author of the epistle wanted Timothy in the text to know the usefulness of the Scriptures. In a similar manner, $\mathrm{CAC}$ holds that all actions and prophecies in the church are to be judged by its conformity to the teaching of the Bible (Folarin 2016:69-73). This shows that the CAC agrees completely with the second part of 2 Timothy 3:16 that the Scripture is not only for instruction, it is also for correction, reproof and training in righteousness. Because of a widespread level of theological ignorance among the church ministers however, the effective use of the Bible as a judgment criterion in the church is limited. There is a wide gap between affirming the inerrancy of the Scripture and the interpretation of its texts: While the Bible has no error in its autographs, its interpretations are not inerrant (Feinberg 1980:294.; cf. Lagoon 2015:n.p.). This shows that the best interpretations of Bible texts are still liable to error and efforts should be made periodically to improve on past interpretations (Folarin 2016:68). The view of CAC on the inspiration of the Bible thus indicates that the church belongs to mainstream Christianity.
Another issue of interest to this research is the way CAC members understood their progenitors' view of the authority of the Bible. Responses gathered on this from the CAC pastors, elders, deaconesses and members of the church are summarised in Table 2.

According to Table 2, item 1a, 170 (44.4\%) of 383 respondents were of the view that the founding fathers and mothers of CAC held that the Bible was binding only on Christians on moral issues. Analysis of item 1a shows that 46 of these came from the Northern region while the remaining 124 interviewees came from the Southwest region. Those who were of the view that the progenitors of the CAC held that the Bible has binding authority on everyone alike on moral issues were 194 (50.7\%) of 383 respondents. Further analysis of Table 2, item $1 b$, reveals that 56 of these came from the Northern region and the remaining 138 interviewees came from the Southwest region. Responses to items $2 a$ and $2 b$ held that the Bible is expected to have binding power over people but they disagreed on who should be subjected to the authority. One hundred and ninety four people responded that the progenitors were of the view that the authority of the Bible be imposed on everyone, including unbelievers, but 170 people limited its application to only Christians. The respondents appeared to be evenly distributed $(50.7 \% \mathrm{cp}$. $44.4 \%$ ). Only 19 (item 2c) out of the 383 interviewees opted not to respond to the test item. The belief of the CAC patriarchs and matriarchs that the Bible has normative power on behaviour is understandable as Christianity is expected to exert notable influence on one's lifestyle (cf. James 1:22-25), particularly when CAC emerged from a holiness movement. The founding fathers and mothers of the CAC were Puritanical, and were almost legalistic in their understanding of Christian living. They used the Bible like a moral textbook (Akinsulure 2017). The influence of the Bible on the moral quality of the Nigerian society is however more complex than is often admitted. The influence of the Bible on ethical norms in the Nigerian society is indirect and comes from Christians working in public places and persuasions

TABLE 2: Members' perception of progenitors view on the authority of the Bible.

\begin{tabular}{|c|c|c|c|c|c|c|}
\hline \multirow[t]{3}{*}{ Item } & \multicolumn{6}{|c|}{ Responses } \\
\hline & \multicolumn{2}{|c|}{ North } & \multicolumn{2}{|c|}{ Southwest } & \multicolumn{2}{|c|}{ Total } \\
\hline & $n$ & $\%$ & $n$ & $\%$ & $n$ & $\%$ \\
\hline \multicolumn{7}{|l|}{ Authority of the Bible on morality } \\
\hline The Bible is binding only on Christians on moral issues & 46 & 41.1 & 124 & 45.8 & 170 & 44.4 \\
\hline $\begin{array}{l}\text { The Bible is binding on everyone including non-Christians on moral } \\
\text { issues }\end{array}$ & 56 & 50.0 & 138 & 50.9 & 194 & 50.7 \\
\hline No response & 10 & 8.9 & 09 & 3.3 & 19 & 4.9 \\
\hline \multicolumn{7}{|l|}{ Authority of the Bible on only issues of faith } \\
\hline The Bible is binding on Christians only on issues of faith & 43 & 38.4 & 122 & 45.0 & 165 & 43.0 \\
\hline The Bible is binding on Christians on all areas of life & 64 & 57.1 & 145 & 53.5 & 209 & 55.0 \\
\hline No response & 05 & 4.5 & 04 & 1.5 & 09 & 2.0 \\
\hline Sub Total & 112 & 100.0 & 271 & 100.0 & 383 & 100.0 \\
\hline \multicolumn{7}{|l|}{ Authority of the Bible on all the issues } \\
\hline $\begin{array}{l}\text { The Bible is binding on all issues on which it comments including } \\
\text { science }\end{array}$ & 89 & 79.5 & 215 & 79.3 & 304 & 79.4 \\
\hline The Bible is not binding on issues that are outside of faith & 14 & 12.5 & 41 & 15.1 & 55 & 14.4 \\
\hline No response & 09 & 8.0 & 15 & 5.6 & 24 & 6.2 \\
\hline Sub Total & 112 & 100.0 & 271 & 100.0 & 383 & 100.0 \\
\hline
\end{tabular}


through sermons and evangelistic outreaches. Some ethical norms were bequeathed to the country by its former Colonial masters. Some wrongly interpret all Colonial inheritances as Christian. Being a multi-religious country, Nigeria has at no time been administered by direct application of the Bible. Christ Apostolic Church expected Christianity to influence the practice of its members in the public spaces. That was the standard, although in practice it has not always been so.

Table 2, item $2 b$, reveals CAC members' perception of their progenitors' view on the authority which the Bible has on issues of faith. Item $2 \mathrm{a}$ shows that $165(43.0 \%)$ of 383 interviewees held that the Bible had binding power on Christians only on issues of faith. Forty-three of these came from the Northern region while 122 respondents came from the Southwest region. Item $2 \mathrm{~b}$ on the contrary reveals that $209(55.0 \%)$ of the 383 interviewees held that the early teaching of CAC was that the Bible should control all areas of a Christian's life. The breakdowns of the respondents with this understanding are 64 from the Northern region and 145 from the Southwest region. Supports for the claim that the Bible be comprehensively normative on Christians are 64 respondents from the Northern region and 145 from the Southwest region. The difference in the responses to the two items in term of percentage are $43.0 \%-55.0 \%$, and these are close. The common denominator however is that both sides agreed that the progenitors of CAC held that the Bible is normative for Christians although the disagreed on the extent. Only $9(2.0 \%)$ of the respondents volunteered no response and the figure was minimal.

Table 2, item 3, shows CAC members' perception of their progenitors' view on the binding authority of the Bible on issues on which it comments. Item 3a shows that 304 (79.4\%) of 383 interviewees held that the Bible has controlling power over all issues on which it comments. The breakdowns of the respondents to this item were 89 from the Northern region and 215 from the Southwest region. Item $3 b$ on the contrary shows that 55 interviewees $(14.4 \%)$ believed that CAC founding fathers and mothers held that the Bible does not have binding power over issues that are outside faith. Only 24 interviewees refused to respond to the test question and they amount only to $6.2 \%$ of the total respondents. The conclusion from the above is that in CAC, the Bible is regarded as authoritative on all issues. This has occasionally led to conflict between professed faith of the church and science, exemplified in the sanction of those who used medicines and visited medical doctors.

Table 3, item 1, reveals the opinion of CAC members on the contemporary view of church members on the authority of the Bible on modern issues. The major finding of Table 3 is in item 2 in which 355 (92.7\%) of the 383 interviewees held that the Bible is still relevant to and binding on the contemporary world. The breakdowns of the responses reveal that 99 of the respondents came from the Northern region and 256 from the Southwest region. By contrast, Table 3, item 1, reveals that only $19(5.0 \%)$ of the 383 interviewees held that the Bible is
TABLE 3: Contemporary view of CAC members on the authority of the Bible.

\begin{tabular}{|c|c|c|c|c|c|c|}
\hline \multirow[t]{3}{*}{ Item } & \multicolumn{6}{|c|}{ Responses } \\
\hline & \multicolumn{2}{|c|}{ North } & \multicolumn{2}{|c|}{ Southwest } & \multicolumn{2}{|c|}{ Total } \\
\hline & $n$ & $\%$ & $n$ & $\%$ & $n$ & $\%$ \\
\hline $\begin{array}{l}\text { The Bible is too old to be } \\
\text { binding on contemporary } \\
\text { Christians }\end{array}$ & 10 & 8.9 & 09 & 3.3 & 19 & 5.0 \\
\hline $\begin{array}{l}\text { The Bible is still relevant } \\
\text { and binding in the } \\
\text { contemporary world }\end{array}$ & 99 & 88.4 & 256 & 94.5 & 355 & 92.7 \\
\hline No response & 03 & 2.7 & 06 & 2.2 & 09 & 2.3 \\
\hline Sub Total & 112 & 100.0 & 271 & 100.0 & 383 & 100.0 \\
\hline
\end{tabular}

CAC, Christ Apostolic Church.

too old to be binding on contemporary issues of life. Only 9 $(2.3 \%)$ of the 383 respondents refused to respond to the interview item and that figure is insignificant.

The CAC is therefore on a strong Evangelical-Pentecostal footing with its unquestionable acceptance of the Bible as God's word with all its attending implications. Of course, scholars of religion are reluctant to accept that copies and translations of the Scriptures are without error and this leaves CAC not only as a fundamentalist but also as a hyperfundementalist church.

\section{Conclusion}

This article first identified the tenet of CAC on inspiration and authority of Scriptures. It then examined the theological context in which the CAC article of faith on inspiration and authority of the Bible emerged. It pointed out that the article of faith was inherited from the Evangelical theology of inerrancy of Scriptures which was held by the churches from where the founding fathers and mothers of CAC came. It pointed out that the unique dimension added to the belief on the inspiration of the Bible by the past and present members of CAC is that the inerrancy, which is verbal and plenary, covers even the various local vernacular versions of the Bible. Again, CAC holds that the Scriptures have controlling authority not only on Christians but also on non-Christians on all issues. All these indicate that the church has a very high view of the inspiration of the Scriptures.

\section{Acknowledgements Competing interests}

The author declares that he has no financial or personal relationships which may have inappropriately influenced him in writing this article.

\section{References}

Adelakun, A.J., 2017, interviewed by George O. Folarin on Obafemi Awolowo University Campus, Ile-Ife on 16 July.

Ademiluka, S.O., 2006, 'The use of imprecatory Psalms in African context', African Journal of Biblical Studies, 23(2), 53-62.

Adeogun, J.O., 2005, 'Psalter: A tool of liberation in Aladura Churches', in S.O. Abogunrin (ed.), Decolonization of Biblical Interpretation in Africa, Nigerian Association for Biblical Studies, Ibadan.

Adeoye, M.A., 2017, interviewed through phone by G.O. Folarin on 29 July.

Akinsulure, S.O., 2017, interviewed by George O. Folarin in CAC Isegun Moore pastorium, lle-Ife on 25 August. 
Alabi, D.O. \& Ariri-Chidomere, A.C., 2017, 'A critical assessment of the use of Psalms in an African Indigenous Church', in J.D. Gwamna, A.O. Dada, H. Amolo (ed.), The present state and the future of Biblical studies in Africa: Essays in honour of present state and the future of Biblical studies in Africa: Essays in honour
Samuel Oyinloye Abogunrin, Nigerian Association for Biblical Studies, Ibadan.

Arndt, W.F. \& Gingrich, F.W., 1957, A Greek-English Lexicon of new testament and other early Christian literature, 4th Rev. \& August edn., Chicago Press, London.

Babajide, D.O., 1980, Iwe ibeere ati idahun Ijo C.A.C, Self Published, llesa.

'Chicago Statement of Biblical Inerrancy', n.d., n.p., viewed 16 July 2017, from http:// www.bible-researcher.com/chicago1.html

Christ Apostolic Church, 1961, Christ Apostolic Church constitution and doctrines, the Supreme Council, Ibadan.

Christ Apostolic Church, 1970, Christ Apostolic Church constitution and doctrines, Christ Apostolic Church Missionary Headquarters, Ibadan.

Christ Apostolic Church, 1995, Christ Apostolic Church (Worldwide) constitution and doctrines, CAC Publicity Department, Ibadan.

Christ Apostolic Church, 1998, Christ Apostolic Church constitution and doctrines, Christ Apostolic Church, Agege.

Christ Apostolic Church, n.d., 'The tenets of CAC', n.p., viewed 16 July 2017, from http://cacworldwideonline.org/cac_tenets.html

Drury, C., 2001, 'The Pastoral Epistles', The Oxford bible commentary, in J. Barton \& J. Muddiman (ed.), Oxford Press, Oxford.

Duffield, G.P. \& Cleave, N.M.V., 1983, Foundations of Pentecostal theology, L.I.F.E Bible College, Los Angeles, CA.

Feinberg, P.D., 1980, 'The meaning of inerrancy', Inerrancy, Zondervan, Grand Rapids, MI.

Folarin, G.O., 2013, 'The origin, development, and a brief appraisal of the doctrine of the Baptism in the Holy Spirit in Christ Apostolic Church, Nigeria', HTS Teologiese Studies/Theological Studies 69(1), Art. // 1333, 1-8. https://doi.org/10.4102/hts. v69i1.1333

Folarin, G.O., 2016, 'Biblical prophecy: A factor for church growth', Babajide Journa (BAJOR): Biblical Prophecy, A Factor for Church Growth, 2(1), 69-73.

Folarin, G.O., 2017, Data gathered for this research from selected church members of Christ Apostolic Church from the Northern and Southwest regions of Nigeria.

Hendriksen, W., 1957, New testament commentary: Exposition of Pastoral epistles, Baker Book House, Grand Rapids, MI.

Hunter, J.D., 1963, American evangelism: Conservative religion and the quandary of modernity, Rutgers University Press, New Brunswick.

International Council of Biblical Inerrancy, n.d., 'The Chicago Statement of Biblical Inerrancy', viewed 16 July 2017, from http://library.dts.edu/Pages/TL/Special/ ICBI_1.pdf. It was produced in 1978, and the document is kept in the library of Dallas Theological Seminary.

Jeanrond, W.G., 1992, 'History of Biblical Hermeneutics', in D.N. Freedman (ed.), The anchor Bible dictionary, vol. 3, pp. 433-443, DoubleDay, New York.

Kay, W.K., 2004, 'Pentecostals and the Bible', Journal of the European Pentecostal Theological Association, 24, 71-83. https://doi.org/10.1179/jep.2004.24.1.006

Kenyon, F.G., 2011, Our Bible and the ancient manuscripts, Wipf and Stock Publishers, Eugene, OR.

Lagoon, S., 2015, 'Accommodation or compromise: The ongoing battle for the Bible', Defending Inerrancy, n.p., viewed 27 July 2017, from http://defendinginerrancy. com/accommodation-or-compromise/

Lindsell, H., 1976, 1981, The battle for the Bible: The book that rocked the Evangelical world, Zondervan Publishing House, Grand Rapids, MI.
Litke, S., 2012, 'Is the Bible reliable? Seven questions', n.p., O Bible.org, viewed 30 August 2017, from https://bible.org/article/bible-reliable $\%$ E2 $\% 80 \% 94$ sevenquestions

Longman, T. (ed.), 2013, The Baker illustrated Bible dictionary, Electronic edn., n.p., Baker, Grand Rapids, MI.

McKim, D.K., 1992, 'Scriptural authority: Biblical authority and the protestant reformation', in D.N. Freedman (ed.), The anchor Bible dictionary, vol. 5, pp. 1032-1035, DoubleDay, New York.

Morris, R.A., 2012, 'A Biblical and Theological analysis of specific tenets of word of faith theology: Pastoral implications for the Church of God,' a $\mathrm{PhD}$ dissertation submitted to South African Theological Seminary, Bryanston, South Africa.

Ockenga, H.J., 1976, 1981, 'Foreword', in Harold Lindsell, The battle for the Bible: The book that rocked the Evangelical world, pp. i-vii, Zondervan Publishing House, Grand Rapids, MI.

Ogunkunle, C.O., 2000 'Imprecatory Psalms: Their forms and uses in ancient Israel and some selected Churches in Nigeria', An unpublished PhD thesis Submitted to the Department of Religious Studies, University of Ibadan.

Ogunkunle, C.O., 2017, 'A critical assessment of the use of Psalms in African indigenous churches', in J.D. Gwamna, A.O. Dada, H. Amolo (ed.), The present state and the churches', in J.D. Gwamna, A.O. Dada, H. Amolo (ed.), The present state and the
future of biblical studies in Africa: Essays in honour of Samuel Oyinloye Abogunrin, pp. 101-112, Nigerian Association for Biblical Studies, Ibadan.

Ogunlowo, N., 2006, interviewed by George O. Folarin in Ibadan.

Olanrewaju, I.O., 1998, The efficacious power of Psalms in daily devotion, Awosanm Press, Suleja.

Olayiwola, D.O., 2017, interviewed with David O. by George O. Folarin on Obafemi Awolowo University Campus, lle-Ife on 17 July.

Oshitelu, G.A., 2007, History of the Aladura (Independent) Churches: 1918-1940, Hope Publications, Ibadan.

Oshun, C.O., 2016, 'A place for prophecy: An aladura perspective of prophecy, prophets and Nigeria's prophetic movements', Babajide Journal (BAJOR): Biblical Prophecy: A Factor for Church Growth 2(1), 20-52.

Otten, B.J., 1922, A manual of the history of dogmas, vol. 1, Richmond Heights, St. Louis, MO, Otten's comment here was on 'dogmas' which involves 'an opinion determined by authority, a decree or an edict or a precept'.

Ryrie, C.C., 1972, A survey of Bible doctrines, Moody, Chicago, IL.

Slick, M., n.d., 'What is verbal plenary inspiration of the Bible?' Christian Apologetics and Research Ministry, n.p., viewed 16 July 2017, from https://carm.org/what-isverbal-plenary-inspiration-of-the-bible

Steiner, M.A., 2006, The rhetoric of operation rescue, T\&T Clark International, Edinburgh.

Ugwueye, L.E. \& Uzuegbunam, E.N., 2013, 'An appraisal of the use of Psalm 35 as 'dangerous prayer' in Mountain of Fire and Miracle (MFM) Church', African Research Review: An International Multidisciplinary Journal 7(1), n.p., viewed 16 July 2017, from https://doi.org/10.4314/afrrev.v7il.2

White, N.J.D., 1956, 'The first and second epistles to Timothy', in W.R. Nicoll (ed.), The expositor's Greek testament, vol. 4, pp. 175-176, Georg H. Doran Co., New York.

Yoder, J. O. \& Martin, H.S., 1985, Biblical inerrancy and reliability, Fellowship of Concerned Mennonites, Harrisonburg, VA.

Yong, A., 2011, 'Reading scripture and nature: Pentecostal hermeneutics and their implications for the contemporary evangelical theology and science conversation', Perspectives on Science and Christian Faith 63(1), 3-15. 